\title{
The CNS microvascular pericyte: pericyte-astrocyte crosstalk in the regulation of tissue survival
}

\author{
Drew Bonkowski ${ }^{1,2}$, Vladimir Katyshev $^{1,3}$, Roumen D Balabanov ${ }^{4}$, Andre Borisov ${ }^{5}$, Paula Dore-Duffy ${ }^{1 *}$
}

\begin{abstract}
The French scientist Charles Benjamin Rouget identified the pericyte nearly 140 years ago. Since that time the role of the pericyte in vascular function has been difficult to elucidate. It was not until the development of techniques to isolate and culture pericytes that scientists have begun to understand the true impact of this unique cell in the maintenance of tissue homeostasis. In the brain the pericyte is an integral cellular component of the blood-brain barrier and, together with other cells of the neurovascular unit (endothelial cells, astrocytes and neurons) the pericyte makes fine-tuned regulatory adjustments and adaptations to promote tissue survival. These regulatory changes involve trans-cellular communication networks between cells. In this review we consider evidence for cellto-cell crosstalk between pericytes and astrocytes during development and in adult brain.
\end{abstract}

\section{Review}

\section{Introduction}

The blood-brain barrier (BBB) regulates the passage of nutrients, essential components, proteins, chemical substances and microscopic organisms between the bloodstream and the parenchymal tissue. The anatomical constituents of the BBB are the endothelial cells (EC), pericytes, and basal lamina (matrix proteins) that with astrocytes, neurons, and possibly other glial cells, comprise the neurovascular unit [1]. Together, the cells of the neurovascular unit adapt to environmental changes and make fine-tuned regulatory decisions that maintain homeostasis and promote tissue survival [1-4]. Nowhere is such tight regulation more important than in the brain where bioenergetic and metabolic homeostasis is integral for neuronal survival $[1,2]$. Dysregulation at the neurovascular level is linked to many common human CNS pathologies, making the unit a potential target for therapeutic intervention [1-4].

The role of the CNS pericyte in the neurovascular unit is still unclear although with improved culturing techniques and the use of genetically engineered animals it has become increasingly clear that pericytes are integral to $\mathrm{BBB}$ function $[3,4]$. It is known that pericytes are highly complex regulatory cells that communicate with

\footnotetext{
* Correspondence: pdduffy@med.wayne.edu

${ }^{1}$ Department of Neurology, Wayne State University School of Medicine, 421 East Canfield Road, Detroit, Michigan 48201, USA

Full list of author information is available at the end of the article
}

ECs and other cells of the neurovascular unit such as neurons by direct physical contact and through autocrine and paracrine signaling pathways [3-9]. However, while there is abundant indirect evidence there is little direct evidence of pericyte-astrocyte communication. In this review we will summarize what is known about pericyte-astrocyte transcellular communication. We will discuss vascular development, BBB function and regulation of the neurovascular unit. The potential role of pericyte-astrocyte crosstalk in development of disease pathology will also be covered.

\section{Pericytes}

Pericytes were described over 100 years ago in 1873 by the French scientist Charles-Marie Benjamin Rouget and dubbed the Rouget cell [10]. The Rouget cell was renamed in the early 1900 s to reflect its anatomical location with in the microvasculature abluminal to the EC and luminal to parenchymal cells (reviewed in [11]). In the brain, pericytes are located in pre-capillary arterioles, capillaries and post capillary venules. They synthesize and deposit elements of the basal lamina and are totally surrounded by this vascular compartment [3-7]. Pericytes are local regulatory cells that are important for the maintenance of vascular homeostasis and hemostasis, and are a source of adult pluripotent stem cells $[12,13]$. Pericytes are important cellular constituents of the $\mathrm{BBB}$ and actively communicate with other cells of the neurovascular unit such as EC, astrocytes, and neurons. While the communication networks involving 
pericytes and endothelial cells have been considered in a number of publications, less is known of the cell-to-cell communication involving astrocytes.

Since its original discovery there has been much confusion and controversy about the pericyte as reflected by the numerous conflicting publications and definitions found in the literature. The pericyte has been referred to as: a) A contractile cell that surrounds the capillary in a tunic-like fashion [10]. b) A branching contractile cell on the abluminal wall of a capillary. c) A peculiar elongated, contractile cell wrapped around pre-capillary arterioles 'outside' the basement membrane [14]. d) A relatively undifferentiated connective tissue cell in the capillaries or other small blood vessels also called the adventitial cell [15]. e) A smooth muscle/pericyte or smooth muscle cell of the capillaries [16,17]. f) A broad flat cell with slender projections that wraps around the capillaries [17]. g) A mesenchymal stem-like cell, associated with the walls of small blood vessels. As a relatively undifferentiated cell, it serves to support these vessels, but it can differentiate into a fibroblast, smooth muscle cell, or macrophage as well other cell populations if required $[3,5-7,12,13,18,19]$. h) A pluripotent or pericyte progenitor cell [13].

In the mature CNS capillary, the pericyte is located between the EC and parenchymal astrocytes and neurons and is surrounded by the basal lamina [3-7]. Pericytes have a prominent round nucleus that clearly differs in shape from the elongated cigar shaped nucleus of the EC. The pericyte extends long processes that extend over the vessel wall. The morphological pattern of projections appears to be somewhat heterogeneous [13]. Pericyte projections can extend around the capillary as originally described by Rouget [10]. The classic wrapping pattern is also somewhat heterogeneous. The most common association of the pericyte with the capillary is one in which the pericyte processes are large and broad and span a continuous surface of the vessel. Alternatively these processes may form finger-like projections that are more confined and ensheath a more finite portion of the vessel surface. A third pattern of pericyte orientation in the microvessel involves a retraction of projections with protrusion of the cells away from the capillaries this represents a migrating pericyte [20]. Pericytes may also extend along the axis of the capillary. It is unclear whether morphological differences in pericyte coverage represent changes in pericyte function. It is clear however that pericytes can migrate away from the capillary surface during angiogenesis, in response to stress stimuli [20-24] and possibly under other conditions [13]. In normal capillaries the wrapping pattern predominates but under pathological conditions the migrating patterns increase [24] and are associated with upregulation of cell surface proteases $[20,21,25]$.
The CNS pericyte is surrounded by the basal lamina on all sides. During development and during angiogenesis the pericyte, assisted by nearby astrocytes discussed below, deposits basal lamina components [3,4,7,13,25-32]. Even extended pericyte projections, observed using electron microscopy, have a thin layer of basal lamina. The basal lamina has been shown to become thicker or thinner in response to stress stimuli [24,33-36]. Changes in the basal lamina can be directly associated with pericyte expression of proteases [20,24,25,37-41] and ultimate migration from its vascular location $[20,33,34,42]$.

The intact basal lamina may provide anchoring and structural integrity to the capillary but it may also be involved in regulation of pericyte function and differentiation. It seems intuitive that there must be a reason why the pericyte is surrounded by laminal proteins. Av $\beta 8$ integrin is important in neurovascular cell adhesion $[27,43]$. Pericytes encased in the basal lamina or exposed to laminal proteins do not usually differentiate (Dore-Duffy, unpublished observations). Thus migration through the basal lamina is necessary before pericytes can function in their stem cell capacity [13]. Regulation at the level of the basal lamina may also be integral to vascular adaptability to an ever-changing environment and to pericyte signaling mechanisms [24].

In its pericapillary location, the pericyte may signal nearby ECs $[3,4,13,40,44,45]$, astrocytes $[46,47]$, neurons, smooth muscle cells and perhaps other pericytes [13]. Pericyte-EC contacts include peg and socket arrangements $[8,48]$ and gap junctions [49-52]. Gap junctions allow pericytes to communicate with ECs through the exchange of ions and small molecules. Peg-and-socket contacts enable pericytes to penetrate through the basal lamina and make contact with other cells and nearby vessels $[8,48,53]$. Junction complexes including adhesion plaques also support transmission of contractile forces from pericytes to other cells. Pericyte gap junctions contain $\mathrm{N}$-cadherin, a variety of adhesion molecules, $\beta$-catenin, extracellular matrix (ECM) molecules such as fibronectin, and a number of integrins [50,51]. Thus, pericytes are involved in highly complex signaling cascades that enable this cell to respond to changes in the microenvironment. However, it is unclear whether gap junctions and peg and socket contacts are naturally present or whether they are initiated during changes in functional activity. For example, it is known that pericytes interdigitate with ECs during the early phases of angiogenesis and with neurons during the maturation of newly-formed vessels [54]. These sites of communication are altered under pathological conditions. During cerebral edema or diabetes, gap junctions are substantially decreased or disrupted in retinal pericytes [54-57]. Diabetes-induced changes in gap junctions may be regulated by high 
glucose [56-58]. Pericyte-EC communication via gap junctions is fundamental to the adaptive responses to compromised bioenergetic homeostasis [58]. Crosstalk between ECs, pericytes, as well as astrocytes is involved in regulation of insulin transport [47]. Pericyte/EC crosstalk is also integral to physiological angiogenesis [59], and is likely to be important in adaptation to hypoxic injury and focal capillary contractility.

\section{Pericytes and astrocytes during vasculogenesis and angiogenesis}

Vasculogenesis is the formation of new blood-vessels by differentiation of vascular precursor cells during development. During retinal development, a role for astrocyte-pericyte communication has been established. Retinal vascularization begins in the inner retinal layer and sprouts radially from the optic nerve to reach the periphery of the retina [60]. Subsequently, retinal vessels sprout into the deep retinal layer to vascularize three parallel nerve fiber layers and two plexiform layers. Experiments using retinal models have tested the hypothesis that astrocytes and pericytes influence this process by affecting the composition of the extracellular matrix. Fibronectin, but not laminin, is expressed in zones of vasculogenesis immediately prior to vessel formation. At this time astrocytes and pericytes spread into the tissue and may be involved in the initiation of vasculogenesis. In fact, it is unclear whether platelet-derived growth factor receptors PDGF $\beta \mathrm{R}+/ \mathrm{PDGF} \alpha \mathrm{R}+$ pericytes and/or PDGF $\alpha \mathrm{R}+$ immature astrocytes are the regulating cell type [60]. Increased amounts of fibronectin mRNA suggest that fibronectin is synthesized by cells within this same region. Pericytes are known to synthesize most extracellular matrix protein components [61]. Differentiation of endothelial cells is correlated with the appearance of pericytes in the vessel wall and laminin in the vascular basement membrane. Astrocyte-conditioned medium stimulates fibronectin expression by both primary endothelial cells and pericytes [62]. Astrocyteinduced pericyte synthesis of fibronectin and perhaps laminin is an essential step in the initiation of retinal vasculogenesis [63]. It is, however, unclear whether a similar mechanism functions in the brain.

Vascularization in the brain during development is derived from a preformed perineural vascular plexus and occurs almost exclusively through sprouting angiogenesis that starts at embryonic day 9 in vertebrates [63]. Angiogenesis is the formation of new vessels from existing vessels. Sprouting angiogenesis is an invasive process that involves proteolytic activities required for degradation of the basal lamina, with pericyte and endothelial migration through tissue matrix [63]. During vessel formation, the recruitment of pericytes and astrocytes to newly-forming vascular tubes is closely associated with the formation of tight junctions. At P4, invading vessels are in direct contact with pericytes, but not with astrocytes. With the progression of development, foot processes of astrocytes are gathered around retinal vessels and the maturation of tight junction $\mathrm{ZO}$ 1 in endothelial cells is more clearly defined [64]. Tight junctions can be formed with contact from pericytes without the ensheathment of the astrocytic foot processes. From in vitro studies it is clear that pericytes induce synthesis of both occludin and claudin through the release of angiopoetin-1 [65]. Thus tight junction formation in the BBB could be developed, in part, by cellular interactions between EC and pericytes followed by astrocytes (as reviewed in [66]). The expression of ZO-1 is augmented by astrocytes [67]. Moreover, ZO-1 as well as occludin or claudin together may be biological indicators of barrier maturation [67]. The role of the pericyte in BBB function will be discussed below.

Studies using glial fibrillary acidic protein (GFAP)knockout mice (GFAP-/-) indicate that, although astrocyte foot interactions with the microvasculature are missing, neovascularization and the formation of tight junctions as well as other CNS morphology appears to be natural [68-70]. Astrocyte neuronal interactions are disrupted [70]. These data suggest that astrocyte interaction with the capillaries or neurons is not essential for tight junction formation. Of interest is that GFAP-/mice are prone to hemorrhagic injury [71]. Similar observations were observed by McCarthy and colleagues [44] in studies using animals lacking alphav integrins. In contrast, administration of the gliotoxin 6-aminonicotinamide (6-AN) to chick embryos during both early and late embryonic development showed a good correlation between perivascular glial depletion and BBB impairment suggesting that astroglia do in fact play a role in $\mathrm{BBB}$ prenatal differentiation and must in some way contribute to vascular function [72]. Taken together the results suggest that, while astrocyte formation of end-feet is not essential for tight junction formation, astrocytes are an important component contributing to normal vessel structural integrity. These results may also indicate that pericytes or other CNS cellular components can compensate for the lack of direct astrocyte signaling.

Using in vitro model systems to study vasculogenesis, scientists have learned that both pericytes and astrocytes are involved in formation of capillary structures. Both cell types form endothelial connections with newly forming vessels (Figure 1) realigning themselves according to the same arrangement seen in vivo. Pericytes in co-culture associate with EC more rapidly than astrocytes. In multi-cellular systems involving pericytes, astrocytes, and EC newly forming tubes have the three dimensional structure of a vessel and exhibit both a lumen and tight junctions. Tube formation in triple 

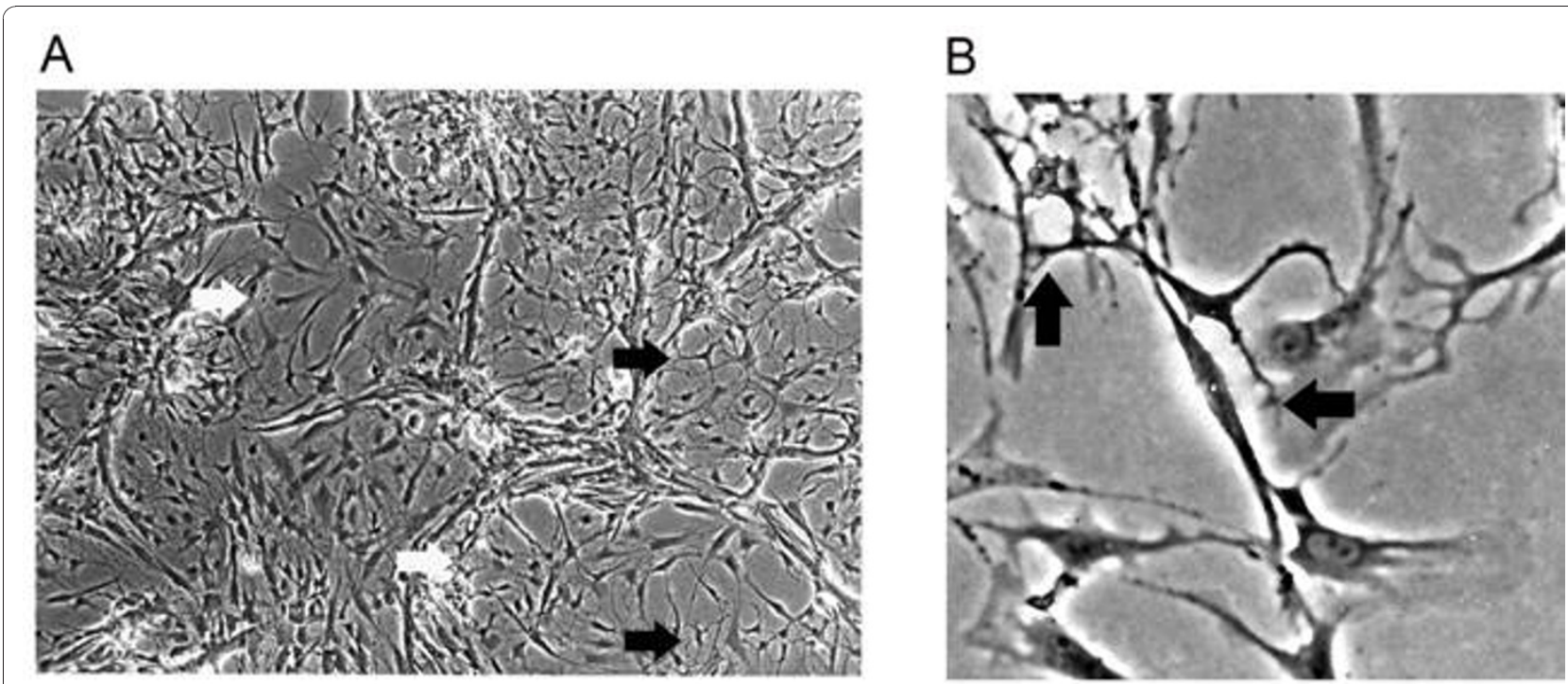

Figure 1 Induction of angiogenesis in triple co-cultures of ECs, pericytes and astrocytes. Primary cells were co-cultured at a ratio of one pericyte to five ECs and to five astrocytes. Cultures were exposed to hypoxia (10\%) to induce angiogenesis (A). Tube formation in triple cultures involved crosstalk between astrocytes and pericytes. White arrows point to pericytes and black arrows point to astrocytes. Photograph was taken using phase contrast at 10x. In (B) we show a close up of an astrocyte making contact with both elongating EC and pericytes. The black arrows point to astrocyte contacts with an elongating EC (left) and one of the two contacts made with a pericyte (right). Pericytes have fewer projections and are more spread out than the astrocytes.

cultures is more rapid than that observed in EC/pericyte or EC/astrocyte, co-cultures. The triple co-culture of pericytes and astrocytes with ECs is thought by most investigators to represent a better model system to study the BBB [73-76]. This may be in part due to the role of agrin, aquaporin 4 , and astrocyte polarity in the BBB [77].

The process of vasculogenesis and differentiation is a complex system that involves crosstalk between numerous cells and is regulated by a number of signaling pathways.

Cell surface proteases expressed on both EC and pericytes exert additional subtle functions in sprouting angiogenesis. These functions involve membrane type-1 matrix metalloproteinase (MT1-MMP), other MMPs, and ADAMs (a disintegrin and metalloproteinase domain) [78]. Proteases modulate the balance between pro- and anti-angiogenic factors by activation of growth factors and chemokines, shedding of chemokines and cytokines from membrane-bound precursors [78], and generation of (matrix) protein fragments that inhibit or activate angiogenesis. Furthermore, they participate in the recruitment of leukocytes and progenitor cells, which contribute to the initiation and progression of angiogenesis. Pericytes are involved in the initiation as well as termination of angiogenesis (as reviewed in [59]). At the initiation of angiogenesis, pericytes are involved in induction of endothelial activation accompanied by augmentation of a variety of proteases [40], adhesion molecules and proteoglycans [79]. Astrocyte expression of tumor necrosis factor converting enzyme (TACE/ ADAM-17) may facilitate pericyte PDGF $\beta R$ signaling mechanisms [80]. Alternatively, at maturation the recruitment of pericytes to the newly-formed endothelial tubes is accompanied by silencing of MMP activities [81]. Recruitment to the newly-formed vessel with termination of angiogenesis involves PDGF $\beta$ [82] as well as transforming growth factor beta (TGF $\beta$ ) [83]. PDGF $\beta$ is thought to be essential for the retention of pericytes in the newly-formed vessels $[84,85]$. Ablation of PDGF $\beta$ results in an embryonic lethal mutation associated with multiple vascular abnormalities $[82,86,87]$.

\section{Pericytes, astrocytes and BBB function 3.1 Contractility}

The concept that pericytes regulate blood flow at the capillary level was originally proposed by Steinach and Kahn in 1903 [88] and Ni in 1922 [89]. Both scientific groups studied the effects of electrical stimulation or exposure to toxic stimuli on capillary diameter. Doré reviewed this area in 1923 [11]. As stated by Doré, [11]: "Until a few years ago the capillaries were regarded as elastic tubes undergoing passive distension in accordance with the general blood pressure, the state of contraction or dilatation of the supplying arterioles, and the nutrition of the vascular walls". The concepts put forward in this 1923 review are on target with exciting more-recently published data [90-92]. 
CNS pericytes have receptors for a large number of vasoactive signaling molecules [3,93-95] suggesting that they have the capacity to be involved in cerebrovascular autoregulation. Expression of alpha muscle actin $(\alpha \mathrm{SMA})$ and the intermediate filament desmin, two proteins found in smooth muscle cells, as well as their adherence to the endovascular cells make them potential candidates for the regulation of capillary diameter and focal capillary blood flow $[3,8,89,91,96-99]$. Electrical stimulation of retinal and cerebellar pericytes is reported to evoke a localized capillary constriction [91,100]. ATP in the retina or noradrenaline in the cerebellum also results in constriction of capillaries by pericytes. Glutamate reverses the constriction produced by noradrenaline [100].

Following simulated ischemia and traumatic brain injury (TBI), capillary pericytes are induced to express $\alpha$ SMA and upregulation of pericyte $\alpha$ SMA is correlated with a focal decrease in capillary diameter [100]. Upregulation of muscle actin was mediated by endothelin-1. Other investigators have shown that capillary contraction can be directly linked to metabolic need $[101,102]$. Exposure to substances that increase pericyte calcium level induces vessel contraction with a concomitant decrease in the capillary lumen diameter [101-103]. The contractile response appears to involve a cascade of events resulting in the inhibition of $\mathrm{Na}+/ \mathrm{Ca} 2+$ exchangers on the EC [103]. Hypoxia, which closes gap junctions, switches the effect of lactate from contraction to relaxation. Thus, pericyte function may be linked with local vascular adaptation to changes in bioenergetic requirements and is intimately linked to astrocyte function.

The calcium-dependent transcription factor NFATc3 is a member of the nuclear factor of activated $\mathrm{T}$ cells (NFAT)-family of transcription factors. NFATc3 is critical for embryonic vascular development and differentiation. Filosa and colleagues investigated the role of glutamate in control of NFATc3 regulation in pericytes [104]. Coronal cortical slices from neonatal rats were subjected to electrical field stimulation or were treated with glutamate receptor agonist (+/-)-1-aminocyclopentane-trans-1,3-dicarboxylic acid (t-ACPD). Electrical field stimulation induced NFATc3 nuclear accumulation in pericytes and astrocytes. The response in pericytes was dependent on metabotropic glutamate receptor (mGluR) activation. NFATc3 nuclear accumulation in pericytes was prevented when astrocytic function was abolished with the gliotoxin L-alpha-aminoadipate. Results suggest that astrocyte glutamate, via mGluR activation, may regulate gene transcription in pluripotent vascular pericytes [104].

\subsection{BBB Permeability}

It has been known for decades that the CNS tissue microenvironment provides the cues for BBB induction and differentiation (as reviewed in $[3,7,90,105])$. Development of the BBB (barrier genesis) is the result of coordinated molecular signaling at the neurovascular interface [106]. Only recently has the canonical Wnt/beta-catenin pathway and the Wnt7a/7b growth factors been implicated in CNS angiogenesis and in BBB induction [86,105-108]. This pathway interacts with other pathways that are crucial for vascular development such as VEGF. Wnt/beta-catenin pathways enhance pericyte mesenchymal differentiation in the presence of TGF-beta3, as demonstrated by increased Sox-9 expression and glycosaminoglycan release into the extracellular matrix. In contrast, transduction of pericytes with a recombinant adenovirus encoding dominant-negative $\mathrm{T}$-cell factor-4 blocked Wnt/beta-catenin signaling and inhibited pericyte differentiation to chondrocytes, leading to reduced Sox-9, reduced type II collagen expression and reduced glycosaminoglycan accumulation $[105,107]$. These data demonstrate that TGF-beta3 induces the chondrogenic differentiation of pericytes by inducing Wnt/beta-catenin signaling and T-cell factor-induced gene transcription. In response to injury, the $\mathrm{Wnt} / \mathrm{beta}$ catenin signaling pathway is enhanced in proliferating NG2 chondroitin sulphate proteoglycan positive cells undergoing differentiation to NG2 glia [109]. It is unclear whether induction of Wnt/beta-catenin signaling in pericytes is responsible for the regulation of the BBB by augmenting the number of NG2+ astrocyte subsets.

Pericytes play a key role in vascular remodeling during development and in the adult. Considerable insight into pericyte biology during development has arisen from studies employing genetically-manipulated mice with disrupted PDGF $\beta /$ platelet PDGF $\beta$ R signaling [84-87,110]. During development, EC-secreted PDGF $\beta$ binds to pericyte PDGF $\beta$ R receptors located on the pericyte plasma membrane resulting in dimerization of the receptor [111]. Pericytes themselves produce PDGF $\beta$ and thus may signal in an autocrine fashion [13]. PDGF stimulates the proliferation, migration, and recruitment of pericytes to the vascular wall of newlyformed blood vessels $[10,14,15,83-87,112]$. PDGF $\beta$ and PDGF $\beta R$ knockout mice have diminished pericyte numbers and a lack of pericyte coverage [87]. The mutation is embryonic lethal with abnormal vasculogenesis $[87,112]$. Loss of pericytes also results in loss of BBB integrity during embryogenesis [113] clearly showing that pericytes are essential to the differentiation of the $\mathrm{BBB}$ during development and have an important role in regulating the $\mathrm{BBB}$ [114]. The exact mechanisms are still somewhat unclear as pericytes have been shown to both induce permeability and to inhibit permeability during development [113-115].

PDGF $\beta$ and PDGF $\beta$ R interactions are also involved in pericyte-mediated regulation of vascular function in the 
adult brain and have a pivotal role in the regulation of the cerebral microcirculation. However, the functional roles of CNS pericytes in the adult and aging brain are less well understood. In the adult animal, it is generally accepted that pericyte association with the microvessel is essential to vascular integrity and that loss of pericytes leads to an increase in vascular leakage and altered vascular function. However, loss of pericytes does not always result in a permanent loss of function and does not always result in disease. Pericytes migrate naturally during the early phases of physiological angiogenesis to make way for growing sprouts [116-119], or in response to stress or injury [20]. Migration from the microvessels following TBI for example, is thought to promote survival as pericytes remaining in their vascular location show signs of degenerative activity [20]. Migration from the vessel involves upregulation of cell surface proteases [20]. Newly-forming vessels both in adult angiogenesis and neovascularization are characterized by increased leakiness. This is transient under normal circumstances but is abnormal in conditions such as pathological angiogenesis. During angiogenesis there is co-migration of pericytes with EC sprouts [116-120] and concomitant proliferation of migrated cells before renewed pericyte coverage and termination of angiogenesis [59]. Pericytes may also be recruited from the bone marrow in adult mice and may have a role in initiation as well as termination of angiogenesis $[84,120]$. Renewed pericyte coverage restores vascular integrity. These observations are supported by data derived using in vitro models of angiogenesis [121-123]. Lack of pericyte termination of angiogenesis alters vascular function and may promote vascular leakiness in part by structural problems with tight junctions [113,114]. Pericytes may also be essential to regulation of transport mechanisms $[86,108]$. Taken together it is easy to speculate that loss of pericyte function may result in the induction of edema and inflammation $[3-7,113,114]$.

Is there a role for astrocytes in maintenance of BBB function? Certainly the astrocytes provide a structural barrier that helps promote vascular integrity. As discussed, microvessels from the GFAP knockout mouse that have no astrocyte end-feet have a tendency to form micro-hemorrhages despite the presence of normal tight junctions $[68,69]$. The interaction of astrocytes with the capillary appears to have an ordered structure as seen in Figure 2a in wild type capillaries. GFAP staining seems to have a fish net orientation that may assist in promoting vascular integrity. Heterozygous animals display a very disordered GFAP staining (Figure 2b). Capillaries from GFAP-/- mice display no staining pattern (Figure 2c). We have found that, to compensate for the loss of astrocyte end-feet, pericytes proliferate. Pericyte to EC ratios are much higher than those observed for wild type mice and for GFAP+/ - heterozygotes (Figure 3; Table 1). This is in contrast to data by others [84] using PDGF deficient animals. The presence of astrogliosis may also alter pericyte function [87].

The integral association of PDGF/PDGFR signaling in maintenance of pericyte function, makes it easy to speculate that astrocytes may be able to regulate pericyte function by the modulation of PDGF $\beta$ signaling. Controlled synthesis of astrocyte $\mathrm{H}_{2} \mathrm{O}_{2}$ alters PDGF signaling and is neuroprotective in conditions of oxidative stress [124-128]. The expression of truncated PDGF $\beta R$ inhibits PDGF signaling [129]. Inhibition is also seen with upregulation of PDGF $\alpha$ R [130]. Heparan sulphate controls the diffusion, and thus the availability of PDGF $\beta$ [131]. Perlecan, a heparin sulfate proteoglycan, has been reported to modulate the BBB [132] and is produced by astrocytes during the stress response [133]. Astrocyte modulation of pericyte function is seen in the injured retina $[60,64]$.

\section{Pericyte-astrocyte communication and disease}

Under normal conditions, the pericyte is relatively quiescent and is essential for vascular stability. Under conditions of stress or injury, the pericyte undergoes phenotypic and functional changes that may include migration, proliferation or differentiation. How these events that include pericyte reprogramming are coordinated at the molecular level needs to be determined. However, it is clear that pericyte dysfunction or the loss of pericytes is likely to play an important role in the pathogenesis of disease.

Pericyte loss or a reduced pericyte-to-EC ratio may be achieved through: 1) migration of pericytes from their microvascular location under pathological or physiological conditions, 2) pericyte death, 3) reduced pericyte turnover or maintenance, and 4) selective alteration of pericyte recruitment to EC that may be associated with dysregulation of angiogenesis and abnormal PDGF $\beta$ signaling. Loss of pericytes with reduced pericyte-to-EC ratios results in a focal increase in permeability. This can be normal as seen in the transient decrease in pericyte-to-EC ratios due to migration of pericytes during endogenous adaptation to chronic mild hypoxia $[59,134]$ or may be abnormal as observed in a number of pathophysiological diseases. Migration may also play a pathogenic role such as that observed in diabetic retinopathy [135]. Decreased pericyte-to-EC ratios have been observed following TBI (20) and stroke [136], multiple sclerosis [137-140], brain tumors [141-143], diabetic retinopathy $[135,144]$, aging $[145,146]$, and in a variety of angiopathies [147]. Pericyte loss may also play a role in Alzheimer's disease, however; enhanced pericyte coverage of some vessels suggests that increased proliferation of pericytes is an adaptation to focal loss of 

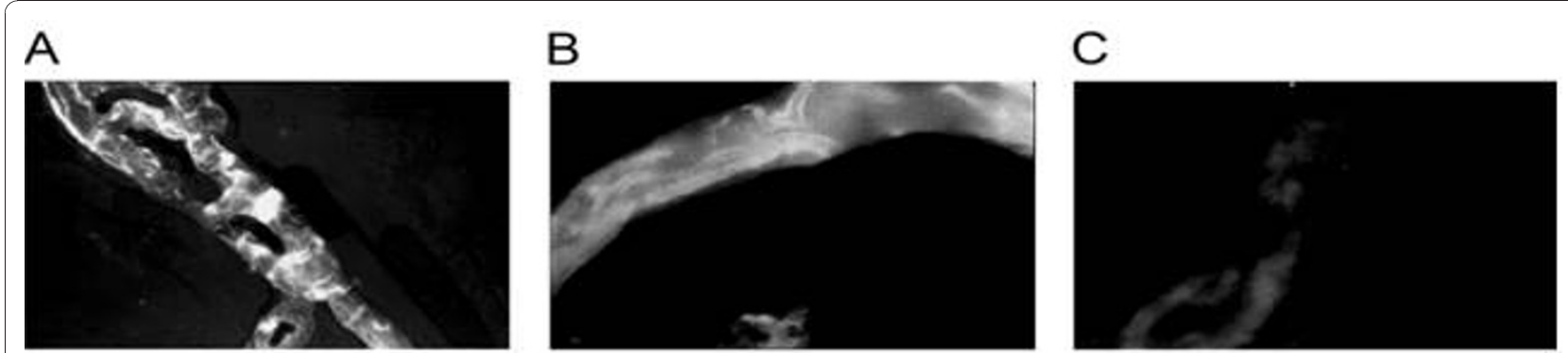

Figure 2 Capillaries [2-6 micron diameter determined by Image J software] were isolated from wild type C57BL/6 mice (A), GFAP -/+ mice (B), and GFAP -/- mice (C) (Jackson Laboratory). Freshly isolated capillaries were allowed to adhere to coverslips fixed and stained for the expression of GFAP (Santa Cruz Biotechnology Inc). Capillaries were visualized on a Leitz fluorescent microscope at 40x and 100x.

bioenergetic homeostasis [14,140,148,149]. Pericyte loss due to cellular degeneration/apoptosis has been shown in hypertrophic scars, keloids [150,151], early diabetic retinopathy $[150,152]$, brain tumors [153-156], liver cancer [157] hyperglycemia [158], and during development [159]. Premature infants have decreased pericyte coverage [160]. A decreased pericyte-to-EC ratio also observed during vascular regression [160].

Increased pericyte coverage may also be an indicator of vascular dysfunction. Pericyte proliferation has been associated with development of muscularization during pulmonary hypertension and is thought to be due to platelet activating factor [161]. Cochlear pericytes in the stria vascularis are markedly affected by acoustic trauma [162]. Levels of the pericyte structural protein, desmin, substantially increase after noise exposure with a corresponding increase in pericyte coverage of vessels. Increased expression levels of desmin were associated with the induction of hypoxia-inducible factor (HIF)1 alpha and the upregulation of vascular endothelial growth factor (VEGF). Inhibition of HIF-1alpha activity decreased VEGF expression levels. Blockade of VEGF activity with SU1498, a VEGF receptor inhibitor, significantly attenuated the expression of desmin in pericytes and may have altered the adaptive process to acoustic stress. Increased pericyte-to-EC ratios are also observed in response to over expression of PDGF $\beta$ [163]. The percentage of vessels covered by pericytes is nearly doubled in myelofibrotic bone marrow [164].

Direct evidence for astrocyte augmentation of pericyte coverage is lacking. However, indirect observations suggest that astrocytes may help augment pericyte proliferation through augmentation of PDGF $\beta$ levels [165] or release of inflammatory mediators [166] that enhance gliosis. In patients with glaucoma, enhanced proliferation is modest but restricted to NG2+ pericytes [167]. Astrocytes and pericytes both express estrogen receptors [167-169]. Astrocytes have been shown to be a source of estrogen following neuronal injury due to an upregulation of aromatase [167]. Estrogens attenuate PDGF $\beta$ signaling in vascular smooth muscle cells $[170,171]$.

On a more subtle level pericyte stem cell activity may be a target for astrocyte modulation. Pericytes have been shown to be multipotent adult stem cells in a number of tissues $[12,13]$. Primary CNS pericytes are capable of differentiating along both the mesenchymal and neural lineages depending on the culture conditions [[12], as reviewed [13]]. In the absence of serum in the presence
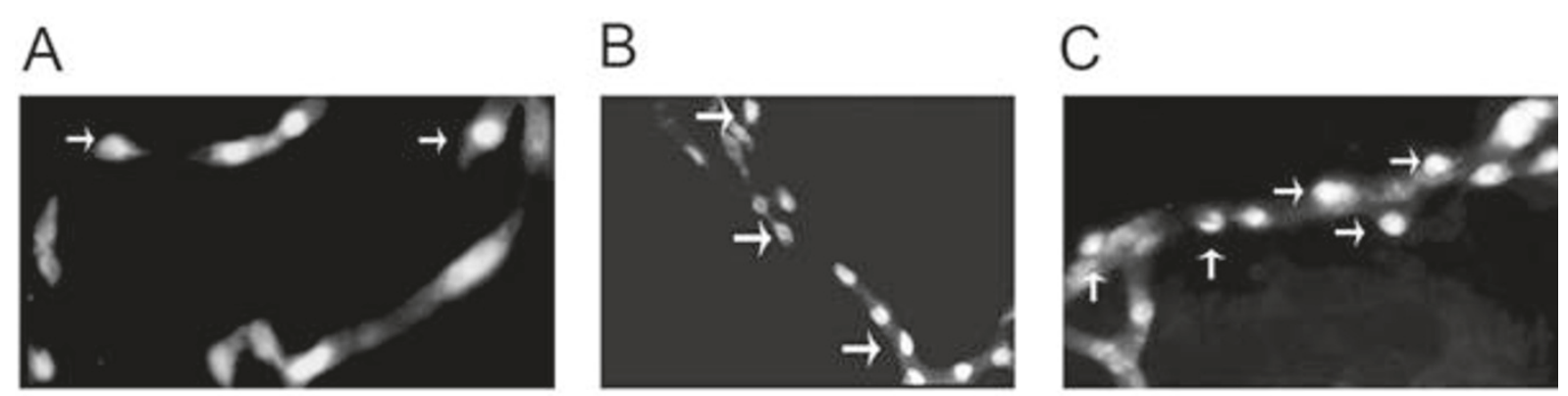

Figure 3 Pericyte-endothelial cell ratios were determined by isolation of capillaries [2-4 micron diameter determined by Image J software] from wild type B6 mice (A); heterozygous GFAP -/+ mice (B) and knockout GFAP -/- mice (C). Freshly isolated capillaries were stained with the fluorescent nuclear dye 4',6-diamidino-2-phenylindole [DAPI]. Round nuclei (pericytes) and elongated nuclei (EC) were counted. Numbers are shown in Table 1. Arrows point to round pericyte nuclei. 
Table 1 Pericyte and endothelial cell numbers in freshlyisolated capillaries from wild type and GFAP knockout mice

\begin{tabular}{llll}
\hline mouse & \#Pericytes* & \# EC* & Fragments counted/exp \\
\hline Wild type & $3 \pm 2$ & $13 \pm 2$ & 40 \\
GFAP -/- & $9 \pm 3$ & $3 \pm 1$ & 55 \\
GFAP +/- & $7 \pm 2$ & $10 \pm 3$ & 42 \\
\hline
\end{tabular}

* Mean +/- SD, $\mathrm{N}=2$ experiments.

of basic fibroblast growth factor (bFGF) cultured adult pericytes form immature NG2+ astrocytes/radial glial cells, NG2+ oligodendrocyte progenitor-like cells and neurons [12]. Thus in response to injury pericytes may undergo neurogenesis. Astrocyte-generated signaling molecules have been shown to augment neurogenesis and differentiation of oligodendrocyte progenitor cells (OPC) [172]. Radial glial cells also retain neurogenic potential $[173,174]$. During injury responses in the kindled animal, astrocyte activation and induction of neurogenesis is due in part to augmentation of nestin expression in pericytes $[175,176]$. Following TBI, Wnt/ beta-catenin signaling occurs in quiescent NG2 progenitors in the cortex, in subcallosal zone (SCZ) progenitors, and in subependymal cells surrounding the central canal. Initially after TBI, beta-catenin signaling was predominantly increased in a subset of NG2+ progenitors in the cortex [110]. One week following injury, the majority of beta-catenin signaling appeared in reactive astrocytes but not other glial cells. Interestingly, cells with beta-catenin signaling were not generated following spinal cord injury. This suggests that although augmentation of pericyte generated stem cell activity and differentiation may be essential to tissue plasticity in adult animals responses may be tissue specific. Further, differentiations within microvascular locations, as well as other abnormal pericyte responses to injury, are likely to be highly deleterious.

\section{Pericytes here and now}

After its identification by Rouget in the late 1800s, relatively little was published about the pericyte until 1902 when the presence of this intriguing cell was confirmed [11]. The development of tissue culture techniques, as well as genetically-manipulated transgenic models in which pericyte coverage is absent or diminished has stimulated considerable interest and provided invaluable tools needed to study pericyte biology. However, while genetically-modified animals can be an important tool some caution should be used when attributing functional roles from observations derived in knockout animals. Adaptive responses to a genetic modification may also confound the interpretation. One must also consider that the phenotype is a function both of the planned genetic manipulation and of potential adaptive responses to the change.
There are a number of examples in the literature that uniquely illustrated this point [177]. Pericytes are integral to the regulation of vascular function as shown in PDGF $\beta$ knockouts. However, PDGF $\alpha$ knockout is also embryonic lethal and displays a similar phenotype $[178,179]$, and together with PDGF $\beta$ is also integral to postnatal development [180]. In the future more targeted manipulations as well as fate mapping will likely clarify the functional role of pericytes in many tissues.

\section{Conclusions}

In this review we discussed evidence that pericytes and astrocytes undergo direct cell-to-cell communication. We also discuss indirect evidence that suggests that astrocytes and pericytes coordinate BBB function. It is clear that this communication is needed for the maintenance of vascular function and must be integral to endogenous adaptation to injury in the adult neurovascular unit. Loss of pericyte function and/or loss of proper astrocyte contact with the $\mathrm{BBB}$ can result in pericyte dysfunction and development of disease. A better understanding of the mechanisms by which pericytes communicate with other cells and how altered communication may result in disease pathology is likely to yield exciting new insights as well as the development of a new therapeutic target in CNS disorders.

\section{Acknowledgements}

The work discussed in this manuscript was supported by grants from the National Institutes of Health NINDS, (NS47672) and the National Multiple Sclerosis Society (CA1042A8, PP1517).

\section{Author details}

${ }^{1}$ Department of Neurology, Wayne State University School of Medicine, 421 East Canfield Road, Detroit, Michigan 48201, USA. ²Department of Neuroscience, University of Michigan, Ann Arbor, Michigan, USA.

${ }^{3}$ Department of Neurology Wayne State University School of Medicine, Detroit, Michigan 48201, USA. ${ }^{4}$ Department of Neurology, Rush University Medical Center, Chicago, Illinois, 60612, USA. ${ }^{5}$ Department of Biology, Wayne State University, Detroit, Michigan 48201, USA.

\section{Authors' contributions}

PDD had primary responsibility for the design of experiments discussed within the review and for the organization and conception of the article. RB performed experiments detailed in the figures and tables as well as development of concepts discussed within. VK conducted experiments to provide some of the data within the manuscript as well as helped with its preparation. DB collected and secured data and interpreted material utilized for the review. AB discussed the organization of the review and possible concepts to be included. All authors have reviewed and approved the final version of the manuscript.

\section{Competing interests}

The authors declare that they have no competing interests.

Received: 10 December 2010 Accepted: 18 January 2011 Published: 18 January 2011

\section{References}

1. del Zoppo GJ: The neurovascular unit in the setting of stroke. J Intern Med 2010, 267:156-171 
2. Nag S, Kapadia A, Stewart DJ: Molecular Pathogenesis of Blood-Brain Barrier Breakdown in Acute Brain Injury. Neuropathol Appl Neurobiol 2010.

3. Balabanov R, Dore-Duffy P: Role of the CNS microvascular pericyte in the blood-brain barrier. J Neurosci Res 1998, 53:637-644.

4. Fisher M: Pericyte signaling in the neurovascular unit. Stroke 2009, 40: S13-15.

5. Sims DE: Recent advances in pericyte biology-implications for health and disease. Can J Cardiol 1991, 7:431-443.

6. Tilton RG: Capillary pericytes: perspectives and future trends. J Electron Microsc Tech 1991, 19:327-344.

7. Shepro D, Morel NM: Pericyte physiology. FASEB J 1993, 7:1031-1038,

8. Nakaoke R, Verma S, Niwa M, Doghu S, Banks WA: Glucose regulated blood-brain barrier transport of insulin: Pericyte-astrocyte-endothelial cell cross talk. IJNN 2007, 3:195-200.

9. Charbord P, Oostendorp R, Pang W, Herault O, Noel F, Tsuji T, Dzierzak E, Peault B: Comparative study of stromal cell lines derived from embryonic, fetal, and postnatal mouse blood-forming tissues. Exp Hematol 2002, 30:1202-1210.

10. Rouget $C$ : Note sur le developpement de la tunique contractile des vaisseaux. Compt Rend Acad Sci 1874, 59:559-562.

11. Doré SE: On the contractility and nervous supply of the capillaries. Brit J Derma 1923, 35:398-404.

12. Dore-Duffy P, Katychev A, Wang X, Van Buren E: CNS microvascular pericytes exhibit multipotential stem cell activity. J Cereb Blood Flow Metab 2006, 26:613-624.

13. Dore-Duffy P: Pericytes: Pluripotent cells of the blood brain barrier. Curr Pharm Des 2008, 14:1581-1593.

14. Blood DC, Studdert VP: Baillière's Comprehensive Veterinary Dictionary London: Baillère Tindall; 1988.

15. Stedman TL: Stedman's Medical Dictionary Baltimore: Williams \& Wilkins; 1995

16. Fabry Z, Fitzsimmons KM, Herlein JA, Moninger TO, Dobbs MB, Hart MN: Production of the cytokines interleukin 1 and 6 by murine brain microvessel endothelium and smooth muscle pericytes. J Neuroimmunol 1993, 47:23-34.

17. Ding R, Darland DC, Parmacek MS, D'Amore PA: Endothelial-mesenchymal interactions in vitro reveal molecular mechanisms of smooth muscle/ pericyte differentiation. Stem Cells Dev 2004, 13:509-520.

18. Pericytes. 2009 [http://en.wikipedia.org/wiki/Pericytes].

19. Krüger M, Bechmann I: Pericytes. In Central Nervous System Diseases and Inflammation. Edited by: Lane TE, Bergmann C, Carson M, Wyss-Coray T. Berlin Heidelberg: Springer-Verlag; 2008:33-43.

20. Dore-Duffy P, Owen C, Balabanov R, Murphy S, Beaumont T, Rafols JA: Pericyte migration from the vascular wall in response to traumatic brain injury. Microvasc Res 2000, 60:55-69

21. Du R, Petritsch C, Lu K, Liu P, Haller A, Ganss R, Song H, Vandenberg S, Bergers $\mathrm{G}$ : Matrix metalloproteinase-2 regulates vascular patterning and growth affecting tumor cell survival and invasion in GBM. Neuro Oncol 2008, 10:254-264.

22. Diaz-Flores L, Gutierrez R, Varela H: Angiogenesis: an update. Histol Histopathol 1994, 9:807-843

23. Nehls $V$, Herrmann $R$, Huhnken M: Guide migration as a novel mechanism of capillary network remodeling is regulated by basic fibroblast growth factor. Histochem Cell Biol 1998, 109:319-329.

24. Nehls V, Schuchardt E, Drenckhahn D: The effect of fibroblasts, vascular smooth muscle cells, and pericytes on sprout formation of endothelial cells in a fibrin gel angiogenesis system. Microvasc Res 1994, 48:349-363.

25. del Zoppo GJ: The neurovascular unit, matrix proteases, and innate inflammation. Ann N Y Acad Sci 2000, 1207:46-49.

26. Wollburg H, Noell S, Mask A, Wolburg-Buchholz K, Fallier-Becker P: Brain endothelial cells and the glio-vascular complex. Cell Tissue Res 2009, 335:75-96

27. del Zoppo GJ, Milner R: Integrin-matrix interactions in the cerebral microvasculature. Arterioscler Thromb Vasc Biol 2006, 26:1966-1975.

28. Stratman AN, Schwindt AE, Malotte KM, Davis GE: Endothelial-derived PDGF-BB and HB-EGF coordinately regulate pericyte recruitment during vasculogenic tube assembly and stabilization. Blood 2010, 116:4720-4730.

29. Kalimo H, Lehto M, Nanto-Salonen K, Jalkanen M, Risteli L, Risteli J, Narva EV: Characterization of the perivascular reticulin network in a case of primary brain lymphoma. Immunohistochemical demonstration of collagen types I, III, IV, and V; laminin; and fibronectin. Acta Neuropathol $1985,66: 299-305$.
30. Canfield AE, Schor AM, Loskutoff DJ, Schor SL, Grant ME: Plasminogen activator inhibitor-type I is a major biosynthetic product of retinal microvascular endothelial cells and pericytes in culture. Biochem J 1989, 259:529-535.

31. Mandarino LJ, Sundarraj N, Finlayson J, Hassel HR: Regulation of fibronectin and laminin synthesis by retinal capillary endothelial cells and pericytes in vitro. Exp Eye Res 1993, 57:609-621.

32. Jeon $H$, Ono M, Kumagai C, Miki K, Morita A, Kitagawa Y: Pericytes from microvessels fragment produce type IV collagen and multiple laminin isoforms. Biosci Biotechnol Biochem 1996, 60:856-861.

33. Díaz-Flores L, Gutiérrez R, Madrid JF, Varela H, Valladares F, Acosta E, MartínVasallo P, Díaz-Flores $L$ Jr: Pericytes. Morphofunction, interactions and pathology in a quiescent and activated mesenchymal cell niche. Histol Histopathol 2009, 24:909-969.

34. Gonul E, Duz B, Kahraman S, Kayali H, Kubar A, Timurkaynak E: Early pericyte response to brain hypoxia in cats: an ultrastructural study. Microvasc Res 2002, 64:116-119.

35. Arismendi-Morillo G, Castellano A: Tumoral micro-blood vessels and vascular microenvironment in human astrocytic tumors. A transmission electron microscopy study. J Neurooncol 2005, 73:211-217.

36. Wiley LA, Rupp GR, Steinle JJ: Sympathetic innervation regulates basement membrane thickening and pericyte number in rat retina. Invest Ophthalmol Vis Sci 2005, 46:744-748.

37. Nielson BS, Sehested M, Kjeldsen L, Borregaard N, Rygaard J, Dan K: Expression of matrix metalloprotease- 9 in vascular pericytes in human breast cancer. Lab Invest 1997, 77:345-355.

38. Arihiro S, Ohtani H, Hiwatashi N, Torii A, Sorsa T, Nagura H: Vascula smooth muscle cells and pericytes express MMP-1, MMP-9, TIMP-1 and type I procollagen in inflammatory bowel disease. Histopathology 2001, 39:50-59.

39. Zozulya A, Weidenfeller C, Galla HJ: Pericyte-endothelial cell interaction increases MMP-9 secretion at the blood brain barrier in vitro. Brain Res 2008, 1189:1-11.

40. Xing C, Arai K, Park KP, Lo EH: Induction of vascular endothelial growth factor and matrix metalloproteinase- 9 via CD47 signaling in neurovascular cells. Neurochem Res 2010, 35:1092-1097.

41. Thanabalasundaram G, Pieper C, Lischper M, Galla HJ: Regulation of the blood-brain barrier integrity by pericytes via matrix metalloproteinases mediated activation of vascular endothelial growth factor in vitro. Brain Res 2010, 1347:1-10.

42. Hughes SJ, Wall N, Scholfield CN, McGeown JG, Gardiner TA, Stitt AW, Curtis TM: Advanced glycation end product modified basement membrane attenuates endothelin-1 induced [Ca2+]i signaling and contraction in retinal microvascular pericytes. Mol Vis 2004, 10:996-1004

43. McCarty JH, Monahan-Earley RA, Brown LF, Keller M, Gerhardt H, Rubin K, Shani M, Dvorak HF, Wolburg H, Bader BL, Dvorak AM, Hynes RO: Defective associations between blood vessels and brain parenchyma lead to cerebral hemorrhage in mice lacking alphav integrins. Mol Cell Biol 2002, 22:7667-7677.

44. McCarty $\mathrm{JH}$ : Cell biology of the neurovascular unit: implications for drug delivery across the blood-brain barrier. Assay Drug Dev Technol 2005, 3:89-95.

45. Hayden MR, Sowers JR, Tyagi SC: The central role of vascular extracellular matrix and basement membrane remodeling in metabolic syndrome and type 2 diabetes: the matrix preloaded. Cardiovasc Diabetol 2005, 4:9.

46. Ryan US, Ryan JW, Whitaker C: How do kinins affect vascular tone? Adv Exp Med Biol 1979, 120A:375-391

47. Filipovich-Rimon T, Fleisher-Berkovich S: Protein synthesis dependent effects of kinins on astrocyte prostaglandin synthesis. Peptides 2010, 31:651-656.

48. Rucker HK, Wynder HJ, Thomas WE: Cellular mechanisms of CNS pericytes. Brain Res Bull 2000, 51:363-369.

49. Carlson EC: Fenestrated subendothelial basement membranes in human retinal capillaries. Invest Ophthalmol Vis Sci 1989, 30:1923-1932.

50. Larson DM, Haudenschild CC, Beyer EC: Gap junction messenger RNA expression by vascular wall cells. Circ Res 1990, 66:1074-1080.

51. Cuevas P, Gutierrez-Diaz JA, Reimers D, Dujovny M, Diaz FG, Ausman JI: Pericyte endothelial gap junctions in human cerebral capillaries. Anat Embryol (Berl) 1984, 170:155-159.

52. Nakamura K, Kamouchi M, Kitazono T, Kuroda J, Matsuo R, Hagiwara N, Ishikawa E, Ooboshi H, Ibayashi S, lida M: Role of NHE1 in calcium 
signaling and cell proliferation in human CNS pericytes. Am J Physiol Heart Circ Physiol 2008, 294:H1700-1707.

53. Allsopp G, Gamble HJ: An electron microscopic study of the pericytes of the developing capillaries in human fetal brain and muscle. J Anat 1979, 128:155-68.

54. Jójárt I, Joó F, Siklós L, László FA: Immunoelectronhistochemical evidence for innervations of brain microvessels by vasopressin-immunoreactive neurons in the rat. Neurosci Lett 1984, 51:259-264.

55. Castejón OJ: Electron microscopic study of capillary wall in human cerebral edema. J Neuropathol Exp Neurol 1980, 39:296-328.

56. Oku H, Kodama T, Sakagami K, Puro DG: Diabetes-induced disruption of gap junction pathways within the retinal microvasculature. Invest Ophthalmol Vis Sci 2001, 42:1915-1920.

57. Kawamura H, Oku H, Li Q, Sakagami K, Puro DG: Endothelin-induced changes in the physiology of retinal pericytes. Invest Ophthalmol Vis Sci 2002, 43:882-888.

58. Li AF, Sato T, Haimovici R, Okamoto T, Roy S: High glucose alters connexin 43 expression and gap junction intercellular communication activity in retinal pericytes. Invest Ophthalmol Vis Sci 2003, 44:5376-5382.

59. Dore-Duffy P, LaManna JC: Physiologic angiodynamics in the brain. Antioxid Redox Signal 2007, 9:1363-1371.

60. Fruttiger M: Development of the mouse retinal vasculature: angiogenesis versus vasculogenesis. Invest Ophthalmol Vis Sci 2002, 43:522-527.

61. Canfield AE, Allen TD, Grant ME, Schor SL, Schor AM: Modulation of extracellular matrix biosynthesis by bovine retinal pericytes in vitro: effects of the substratum and cell density. J Cell Sci 1990, 96:159-169.

62. Jiang B, Liou Gl, Behzadian MA, Caldwell RB: Astrocytes modulate retinal vasculogenesis: effects on fibronectin expression. J Cell Sci 1994, 107:2499-2508.

63. Plate KH: Mechanisms of Angiogenesis in the Brain. J Neuropath Exp Neurol 1999, 58:313-320.

64. Gardner TW, Lieth E, Khin SA, Barber AJ, Bonsall DJ, Lesher T, Rice K Brennan WA Jr: Astrocytes increase barrier properties and ZO-1 expression in retinal vascular endothelial cells. Arterioscler Thromb Vasc Bio 2006, 55:2401-2411.

65. Hori S, Ohtsuki S, Hosoya K, Nakashima E, Terasaki TA: Pericyte-derived angiopoietin-1 multimeric complex induces occludin gene expression in brain capillary endothelial cells through Tie-2 activation in vitro. $J$ Neurochem 2007, 89:503-513.

66. Haseloff RF, Blasig IE, Bauer HC, Bauer H: In search of the astrocytic factor (s) modulating blood-brain barrier functions in brain capillary endothelial cells in vitro. Cell Mol Neurobiol 2005, 25:25-39.

67. Kim JH, Kim JH, Yu YS, Kim DH, Kim KWJ: Recruitment of pericytes and astrocytes is closely related to the formation of tight junction in developing retinal vessels. Neurosci Res 2009, 87:653-659.

68. Benner M, Kisseberth WS, SU Y, Besnard K, Messing A: GFAP promoter direct astrocyte-specific expression in transgenic mice. J Neurosci 1994, 14:1030-1037.

69. Delaney $\mathrm{CL}$, Brenner M, Messing A: Conditional ablation of cerebellar astrocytes in postnatal transgenic mice. J Neurosci 1996, 16:6908-6918.

70. McCall MA, Gregg RG, Behringer RR, Brenner M, Delaney CL, Galbreath EJ, Zhang CL, Pearce RA, Chiu SY, Messing A: Targeted deletion in astrocyte intermediate filament (Gfap) alters neuronal physiology. Proc Natl ACad Sci USA 1996, 93:6361-6366.

71. Nawashiro H, Messing A, Azzam N, Brenner M: Mice lacking GFAP are hypersensitive to traumatic cerebrospinal injury. Neuroreport 1998, 9:1691-1696.

72. Bertossi M, Girolamo F, Errede M, Virgintino D, Roncali L: Effects of 6aminonicotinamide gliotoxin on blood-brain barrier differentiation in the chick embryo cerebellum. Anat Embryol 2003, 207:209-219.

73. Nakagawa S, Deli MA, Kawaguchi H, Shimizudani T, Shimono T, Kittel A, Tanaka K, Niwa M: A new blood-brain barrier model using primary rat brain endothelial cells, pericytes and astrocytes. Neurochem Int 2009, 54:253-263.

74. Al Ahmad A, Gassmann M, Ogunshola OO: Maintaining blood-brain barrier integrity: pericytes perform better than astrocytes during prolonged oxygen deprivation. J Cell Physiol 2009, 218:612-622.

75. Nakagawa S, Deli MA, Nakao S, Honda M, Hayashi K, Nakaoke R, Kataoka Y, Niwa M: Pericytes from brain microvessels strengthen the barrier integrity in primary cultures of rat brain endothelial cells. Cell Mol Neurobiol 2007, 27:687-694
76. Bryan BA, D'Amore PA: Pericytes isolation and use in endothelial/pericyte co-culture models. Methods Enzymol 2008, 443:315-331.

77. Wolburg H, Noell S, Wolburg-Buchholz K, Mack A, Fallier-Becker P: Agrin, aquaporin-4, and astrocyte polarity as an important feature of the blood-brain barrier. Neuroscientist 2009, 15:180-193.

78. Mendelson K, Swendeman S, Saftig P, Blobel CP: Stimulation of plateletderived growth factor receptor beta (PDGFRbeta) activates ADAM17 and promotes metalloproteinase-dependent cross-talk between the PDGFRbeta and epidermal growth factor receptor (EGFR) signaling pathways. J Biol Chem 2010, 285:25024-25032

79. Fukushi J, Makagiansar IT, Stallcup WB: NG2 proteoglycan promotes endothelial cell motility and angiogenesis via engagement of galectin-3 and alpha3beta1 integrin. Mol Biol Cell 2004, 15:3580-3590.

80. Hurtado O, Lizasoain I, Fernández-Tomé P, Alvarez-Barrientos A, Leza JC, Lorenzo P, Moro MA: TACE/ADAM17-TNF-alpha pathway in rat cortical cultures after exposure to oxygen-glucose deprivation or glutamate. $J$ Cereb Blood Flow Metab 2002, 22:576-585.

81. Van Hinsbergh WW, Koolwijk P: Endothelial sprouting and angiogenesis: matrix metalloproteinases in the lead. Cardiovasc Res 2008, 78:203-212.

82. Risau W, Drexler H, Mironov V, Smits A, Siegbahn A, Funa K, Heldin CH: Platelet-derived growth factor is angiogenic in vivo. Growth Factors 1992, 7:261-266.

83. Darland DC, D'Amore PA: TGF beta is required for the formation of capillary-like structures in three-dimensional cocultures of $10 \mathrm{~T} 1 / 2$ and endothelial cells. Angiogenesis 2001, 4:11-20.

84. Hellstrom M, Kalen M, Lindahl P, Abramsson A, Betsholtz C: Role of PDGF-B and PDGFR-beta in recruitment of vascular smooth muscle cells and pericytes during embryonic blood vessels formation in the mouse. Development 1999, 126:3047-3055.

85. Lindblom P, Gerhardt H, Leibner S, Abramsson A, Enge M, Hellstrom M, Backstrom G, Fredriksson S, Landegren U, Nystrom HC, Bergstrom G, Dejana e, Ostman A, Lindahl P, Betsholtz C: Endothelial PDGF-B retention is required for proper investment of pericytes in the microvessel wall. Genes Dev 2003, 17:1835-1840.

86. Armulik A, Abramsson A, Betsholtz C: Endothelial/pericyte interactions. Circ Res 2005, 97:512-523.

87. Bjarnegard M, Enge M, Norlin j, Gustafsdottir S, Fredriksson S, Abramsson A, Takemoto M, Gustafsson E, Fassler R, Betsholtz C: Endothelium-specific ablation of PDGFB leads to pericyte loss and glomerular, cardiac and placental abnormalities. Development 2004, 313:1847-1857.

88. Steinach E, Kahn BH: Echte Contractilität und motorische Innervation der Blutcapillaren. Pflügers Archiv 1903, 97:195, [German].

89. $\mathrm{Ni} \mathrm{TG:} \mathrm{The} \mathrm{active} \mathrm{response} \mathrm{of} \mathrm{capillaries} \mathrm{of} \mathrm{frogs,} \mathrm{tadpoles,} \mathrm{fish,} \mathrm{bats,} \mathrm{and}$ men to various forms of excitation. Amer J Phys 1922, 62:282-309.

90. Peppiatt CM, Howarth C, Mobbs P, Attwell D: Bidirectional control of CNS capillary diameter by pericytes. Nature 2006, 443:700-704.

91. Hamilton NB, Attwell D, Hall CN: Pericyte-mediated regulation of capillary diameter: a component of neurovascular coupling in health and disease. Front Neuroenergetics 2010, 2:5.

92. Bell RD, Winkler EA, Sagare AP, Singh I, Larue B, Deane R, Zlokovic BV: Pericytes Control Key Neurovascular Functions and Neuronal Phenotype in the Adult Brain and during Brain Aging. Neuron 2010, 68:409-412.

93. Quignard JF, Harley EA, Duhault J, Vanhoutte PM, Félétou M: K+ channels in cultured bovine retinal pericytes: effects of beta-adrenergic stimulation. J Cardiovasc Pharmacol 2003, 42:379-388.

94. Cao C, Goo JH, Lee-Kwon W, Pallone TL: Vasa recta pericytes express a strong inward rectifier $\mathrm{K}+$ conductance. Am J Physiol Regul Integr Comp Physiol 2006, 290:R1601-1607.

95. Jackson WF: Potassium channels in the peripheral microcirculation. Microcirculation 2005, 12:113-127.

96. Bondjers C, He L, Takemoto M, Norlin J, Asker N, Hellström M, Lindahl P, Betsholtz C: Microarray analysis of blood microvessels from PDGF-B and PDGF-Rbeta mutant mice identifies novel markers for brain pericytes. FASEB J 2006, 20:1703-1705.

97. Kelley C, D'Amore P, Hechtman HB, Shepro D: Vasoactive hormones and CAMP affect pericyte contraction and stress fibres in vitro. J Muscle Res Cell Motil 1988, 9:184-194

98. Das A, Frank RN, Weber ML, Kennedy A, Reidy CA, Mancini MA: ATP causes retinal pericytes to contract in vitro. Exp Eye Res 1988, 46:349-362.

99. Matthew KE, Herman IM: The pericyte: Cellular regulation of microvascular blood flow. Microvasc Res 2009, 77:235-246. 
100. Anderson DR: Glaucoma, capillaries and pericytes. 1. Blood flow regulation. Ophthalmologica 1996, 210:257-262.

101. Edelman DA, Jiang Y, Tyburski J, Wilson RF, Steffes C: Pericytes and their role in microvasculature homeostasis. J Surg Res 135:305-311.

102. Hughes S, Gardiner T, Hu P, Baxter L, Rosinova E, Chan-Ling T: Altered pericyte-endothelial relations in the rat retina during aging: implications for vessel stability. Neurobiol Aging 2006, 27:1838-1847.

103. Kelley C, D'Amore P, Hechtman HB, Shepro D: Vasoactive hormones and CAMP affect pericyte contraction and stress fibres in vitro. J Muscle Res Cell Motil 1988, 9:184-194.

104. Filosa JA, Nelson MT, Gonzales Bosc LV: Activity-dependent NFATc3 nuclear accumulation in pericytes from cortical parenchymal microvessels. J Physiol Cell Physiol 2007, 293:1797-1805.

105. Liebner S, Plate KH: Differentiation of the brain vasculature: the answer came blowing by the Wnt. J Angiogenes Res 2010, 2:1.

106. Lee HS, Han J, Bai HJ, Kim KW: Brain angiogenesis in developmental and pathological processes: regulation, molecular and cellular communication at the neurovascular interface. FEBS J 2009, 276:4622-4635.

107. Stenman JM, Rajagopal J, Carroll TJ, Ishibashi M, McMahon J, McMahon AP: Canonical WNT Signaling regulates organ-specific assembly and differentiation of CNS vasculature. Science 2008, 322:1247-1250.

108. Daneman R, Agalliu D, Zhou L, Kuhnert F, Kuo CJ, Barres BA: Wnt/betacatenin signaling is required for CNS, but not-CNS, angiogenesis. Proc Natl Acad Sci USA 2009, 106:641-646.

109. White BD, Nathe RJ, Maris DO, Nguyen NK, Goodson JM, Moon RT, Horner PJ: Beta-catenin signaling increases in proliferating NG2 +progenitors and astrocytes during post-traumatic gliogenesis in the adult brain. Stem Cells 2010, 28:297-307.

110. Leveen P, Pekny M, Gebre-Medhin S, Swolin B, Larsson E, Betsholtz C: Mice deficient for PDGF B show renal, cardiovascular, and hematological abnormalities. Genes Dev 1994, 8:1875-1887.

111. Siegfried G, Basak A, Prichett-Pejic W, Scamuffa N, Ma L, Benjannet S, Veinot JP, Calvo F, Seidah N, Khatib AM: Regulation of the stepwise proteolytic cleavage and secretion of PDGF-B by the proprotein convertases. Oncogene 2005, 24:6925-6935.

112. Zlokovic BV: The blood-brain barrier in health and chronic neurodegenerative disorders. Neuron 2008, 57:178-201.

113. Danema R, Zhou L, Amanuel A, Kebede, Barres BA: Pericytes are required for blood-brain barrier integrity during embryogenesis. Nature 2010, 468:223-231.

114. Armulik A, Genove G, Mae M, Nisancioglu MN, Wallgard E, Niaudet C, Liqun H, Norlin J, Lindblom P, Strittmatter K, Johansson BR, Betsholtz C: Pericytes regulate the blood-brain barrier. Nature 2010, 468:557-561.

115. Girolamo F, Virgintino D, Errede M, Capobianco C, Bernandini N, Bertossi M, Roncali L: Involvement of metalloprotease-2 in the development of human brain microvessels. Histochem Cell Biol 2004, 122:261-270.

116. Diaz-Flores L, Gutierrez R, Valladares F, Varela H, Perez M: Intense vascular sprouting from rat femoral vein induced by prostaglandins E1 and E2. Anat Rec 1994, 238:68-76

117. Nehls V, Denzer K, Drenckhahn D: Pericyte involvement in capillary sprouting during angiogenesis in situ. Cell Tissue Res 1992, 270:469-474.

118. Virgintino D, Ozerdem U, Girolamo F, Roncali L, Stallcup WB, Perris R: Reversal of cellular roles in angiogenesis: implications for antiangiogenic therapy. J Vasc Res 2008, 45:129-31.

119. Diaz-Flores L, Gutierrez R, Madrid JF, Varela H, Valladares F, Acosta E, MartinVasallo $P$, Diaz-Flores $L \mathrm{Jr}$ : Pericytes. Morphofunction, interactions and pathology in a quiescent and activated mesenchymal cell niche. Histol Histopathol 2009, 24:909-969.

120. Kokovay E, Li L, Cunningham LA: Angiogenetic recruitment of pericytes from bone marrow after stroke. J Cereb Blood Flow Metab 2006, 26:545-555.

121. Minakawa T, Bready J, Berliner J, Fisher M, Cancilla PA: In vitro interaction of astrocytes and pericytes with capillary-like structures of brain microvessels oendothelium. Lab Invest 1991, 65:32-40.

122. Lai CH, Kuo KH: The critical component to establish in vitro BBB model: Pericyte. Brain Res Brain Res Rev 2005, 50:258-265.

123. Ahmad AA, Taboada CB, Gassmann M, Ogunshola OO: Astrocytes and pericytes differentially modulate blood-brain barrier characteristics during development and hypoxic insult. I Cereb Blood Flow Metab 2010, 10:1038-1045.
124. Haskew RE, Mongin AA, Kimelberg HK: Peroxynitrite enhances astrocytic volume-sensitive excitatory amino acid release via a src tyrosine kinasedependent mechanism. J Neurochem 2002, 82:903-912.

125. Hede SM, Hansson I, Afink GB, Eriksson A, Nazarenko I, Andrae J, Genove G, Westermark B, Nister M: GFAP promoter driven transgenic exprassion of PDGFB in the mouse brain leads to glioblastoma in a Tro53 null background. Glia 2009, 57:1143-1153.

126. Tagami M, Yamagata K, Fujino H, Kubota A, Nara Y, Yamory Y: Morphological differentiation of endothelial cells co-cultured with astrocytes on type-I or type IV collagen. Cell Tissue Res 1992, 268:225-232.

127. Choi MH, Lee IK, Kim GW, Kim BU, Han YH, Yu DY, Park HS, Kim KY, Lee JS, Choi C, Bae YS, Lee BI, Rhee SG, Kang SW: Regulation of PDGF signaling and vascular remodeling by peroxiredoxin II. Nature 2005, 435:347-353.

128. Haskew-Layton RE, Payappilly JB, Smirnova NA, Ma TC, Chan KK, Murphy TH, Guo H, Langley B, Sultana B, Butterfield DA, Santagata S, Alldred MJ, Gazaryan IG, Bell GW, Ginsberg SD, Ratan RR: Controlled enzymatic production of astrocytic hydrogen peroxide protects neurons from oxidative stress via an Nrf2-independent pathway. Proc Natl Acad Sci USA 2010, 107:17385-17390.

129. Ueno H, Colbert H, Escobedo JA, Williams LT: Inhibition of PDGF beta receptor signal transduction by coexpression of a truncated receptor Science 1991, 252:844-848.

130. Zhou T, Liu H, Zhang P, Luo C: Effect of truncated PDGF-Alpha receptor on cellular cycle and proliferation for vascular cells of pulmonary artery. Sichuan Da Xue Xue Bao Yi Xue Ban 2003, 34:31-3.

131. Kurup S, Abramsson A, Li JP, Lindahl U, Kjellen L, Betsholtz C, Genhardt H, Spillmann D: Heparin Sulphate requirement in platelet-derived growth factor B-mediated pericyte recruitment. Biochem Soc Trans 2006, 34:454-455.

132. Deguchi Y, Okutsu H, Okura T, Yamada S, Kimura R, Yuge T, Furukawa A, Morimoto K, Tachikawa m, Ohtsuki S, Hosoya K, Terasaki T: Internalization of basic fibroblast growth factor at the mouse blood-brain barrier involves perlecan, a heparan sulfate proteoglycan. J Neurochem 2002, 83:381-389.

133. Santos-Silva A, Fairless R, Frame MC, Montague P, Smith GM, Toft A, Riddell JS, Barnett Sc: FGF/heparin differentially regulates Schwann cell and olfactory ensheathing cell interactions with astrocytes: a role in astrocytosis. J Neurosci 2007, 27:7154-7167.

134. Al Ahmad A, Taboada CB, Gassmann M, Ogunshola OO: Astrocytes and pericytes differentially modulate blood-brain barrier characteristics during development and hypoxic insult. J Cereb Blood Flow Metab 2010.

135. Pfister F, Feng $Y$, vom Hagen F, Hoffmann S, Molema G, Hillebrands JL, Shani M, Deutsch U, Hammes HP: Pericyte migration: a novel mechanism of pericyte loss in experimental diabetic retinopathy. Diabetes 2008, 57:2495-2502.

136. Duz B, Oztas E, Erginay T, Erdogan E, Gonul E: The effect of moderate hypothermia in acute ischemic stroke on pericyte migration: an ultrastructural study. Cryobiology 2007, 55:279-284.

137. Claudio L, Brosnan CF: Effects of prazosin on the blood-brain barrier during experimental autoimmune encephalomyelitis. Brain Res 1992, 594:233-243.

138. Kunz J, Krause D, Gehrmann J, Dermietzel R: Changes in the expression pattern of blood-brain barrier-associated pericytic aminopeptidase $\mathrm{N}$ (pAP N) in the course of acute experimental autoimmune encephalomyelitis. I Neuroimmunol 1995, 59:41-55.

139. Dore-Duffy P, Balabanov R, Rafols J, Swanborg RH: Recovery phase of acute experimental autoimmune encephalomyelitis in rats corresponds to development of endothelial cell unresponsiveness to interferon gamma activation. J Neurosci Res 1996, 44:223-234.

140. Bolton C: Neurovascular damage in experimental allergic encephalomyelitis: a target for pharmacological control. Mediators Inflamm 1997, 6:295-302.

141. Zlokovic BV: The blood-brain barrier in health and chronic neurodegenerative disorders. Neuron 2008, 57:178-201.

142. Ho KL: Ultrastructure of cerebellar capillary hemangioblastoma. IV. Pericytes and their relationship to endothelial cells. Acta Neuropathol 1985, 67:254-264.

143. Winkler F, Kozin SV, Tong RT, Chae SS, Booth MF, Garkavtsev I, Xu L, Hicklin DJ, Fukumura D, di Tomaso E, Munn LL, Jain RK: Kinetics of vascular normalization by VEGFR2 blockade governs brain tumor response to radiation: role of oxygenation, angiopoietin-1, and matrix metalloproteinases. Cancer Cell 2004, 6:553-563. 
144. Hammes HP, Lin J, Renner O, Shani M, Lundqvist A, Betsholtz C, Brownlee $M$, Deutsch U: Pericytes and the pathogenesis of diabetic retinopathy. Diabetes 2002, 51:3107-3112.

145. Frank RN, Turczyn TJ, Das A: Pericyte coverage of retinal and cerebral capillaries. Invest Ophthalmol Vis Sci 1990, 31:999-1007.

146. Feng Y, Pfister F, Schreiter K, Wang Y, Stock O, Vom Hagen F, Wolburg H, Hoffmann S, Deutsch U, Hammes HP: Angiopoietin-2 deficiency decelerates age-dependent vascular changes in the mouse retina. Cell Physiol Biochem 2008, 21:129-136.

147. Szpak GM, Lewandowska E, Wierzba-Bobrowicz T, Bertrand E, Pasennik E, Mendel T, Stepien T, Leszczynska A, Rafalowska J: Small cerebral vessel disease in familial amyloid and non-amyloid angiopathies: FAD-PS-1 (P117L) mutation and CADASIL. Immunohistochemical and ultrastructural studies. Folia Neuropathol 2007, 45:192-204

148. Wegiel J, Wisniewski HM: Tubuloreticular structures in microglial cells, pericytes and endothelial cells in Alzheimer's disease. Acta Neuropathol 1992, 83:653-658.

149. Stewart PA, Hayakawa K, Akers MA, Vinters HV: A morphometric study of the blood-brain barrier in Alzheimer's disease. Lab Invest 1992, 67:734-742.

150. Yamagishi S, Imaizumi T: Pericyte biology and diseases. Int J Tissue React 2005, 27:125-135.

151. Kischer CW: The microvessels in hypertrophic scars, keloids and related lesions: a review. J Submicrosc Cytol Pathol 1992, 24:281-296.

152. Li W, Yanoff M, Liu X, Ye X: Retinal capillary pericyte apoptosis in early human diabetic retinopathy. Chin Med J (Engl) 1997, 110:659-663.

153. Shojaee N, Patton WF, Hechtman HB, Shepro D: Myosin translocation in retinal pericytes during free-radical induced apoptosis. $J$ Cell Biochem 1999, 75:118-129.

154. Zagzag D, Amirnovin R, Greco MA, Yee H, Holash J, Wiegand SJ, Zabski S, Yancopoulos GD, Grumet M: Vascular apoptosis and involution in gliomas precede neovascularization: a novel concept for glioma growth and angiogenesis. Lab Invest 2000, 80:837-849.

155. Machein MR, Knedla A, Knoth R, Wagner S, Neuschl E, Plate KH: Angiopoietin-1 promotes tumor angiogenesis in a rat glioma model. Am J Pathol 2004, 165:1557-1570.

156. Bexell D, Gunnarsson S, Tormin A, Darabi A, Gisselsson D, Roybon L, Scheding S, Bengzon J: Bone marrow multipotent mesenchymal stroma cells act as pericyte-like migratory vehicles in experimental gliomas. $\mathrm{Mol}$ Ther 2009, 17:183-190.

157. Vermeulen PB, Colpaert C, Salgado R, Royers R, Hellemans H, Van Den Heuvel E, Goovaerts G, Dirix LY, Van ME: Liver metastases from colorectal adenocarcinomas grow in three patterns with different angiogenesis and desmoplasia. J Pathol 2001, 195:336-342.

158. Li W, Liu X, Yanoff M, Cohen S, Ye X: Cultured retinal capillary pericytes die by apoptosis after an abrupt fluctuation from high to low glucose levels: a comparative study with retinal capillary endothelial cells. Diabetologia 1996, 39:537-547.

159. Braun A, Xu H, Hu F, Kocherlakota P, Siegel D, Chander P, Ungvari Z, Csiszar A, Nedergaard M, Ballabh P: Paucity of pericytes in germinal matrix vasculature of premature infants. J Neurosci 2007, 27:12012-12024.

160. Zhu M, Madigan MC, van Driel D, Maslim J, Billson FA, Provis JM, Penfold PL: The human hyaloid system: cell death and vascular regression. Exp Eye Res 2000, 70:767-776.

161. Khoury J, Langleben D: Platelet-activating factor stimulates lung pericyte growth in vitro. Am J Physiol 1996, 270:L298-304.

162. Shi $X$ : Cochlear pericyte responses to acoustic trauma and involvement of hypoxia-inducible factor-1 alpha and vascular endothelial growth factor. Am J Pathol 2009, 174:1692-1704.

163. Song $N$, Huang $Y$, Shi $H$, Yuan S, Ding $Y$, Song $X$, Fu $Y$, Luo $Y$ : Overexpression of platelet-derived growth factor-BB increases tumor pericyte content via stromal-derived factor- 1 alpha/CXCR4 axis. Cancer Res 2009, 69:6057-64

164. Zetterberg E, Alessandro MV, Migliaccio AR, Vainchenker W, Tulliez M, Dickie R, Hasselbalch H, Rogers R, Palmblad J: Pericyte coverage of abnormal blood vessels in myelofibrotic bone marrows. Haematologica 2007, 92:597-604.

165. Vinukonda G, Dummula K, Malik S, Hu F, Thompson Cl, Csiszar A, Ungvari Z, Ballabh : Effect of prenatal glucocorticoids on cerebral vasculature of the developing brain. Stroke 2010, 41:1766-1773.
166. Fioravanzo I, Venturini M, Di Liddo R, Marchi F, Grandi C, Parnigotto PP, Folin M: Involvement of Rat Hippocampal Astrocytes in $\beta$-Amyloid Induced Angiogenesis and Neuroinflammation. Curr Alzheimer Res 2010.

167. Sortino MA, Platania P, Chisari M, Merlo S, Copani A, Catania MV: A major role for astrocytes in the neuroprotective effect of estrogen. Drug Dev Res 2006, 66:126-135.

168. Inman DM, Horner PJ: Reactive nonproliferative gliosis predominates in a chronic mouse model of glaucoma. Glia 2007, 55:942-953.

169. Bukovsky A, Cekanova M, Caudle MR, Wimalasena J, Foster JS, Henley DC, Elder RF: Expression and localization of estrogen receptor-alpha protein in normal and abnormal term placentae and stimulation of trophoblast differentiation by estradiol. Reprod Biol Endocrinol 2003, 1:13.

170. Kappert k, Caglayan E, Huntgeburth M, Baumer AT, Sparwel J, Uebel M, Rosenkranz S: 17Beta-estradiol attenuates PDGF signaling in vascular smooth muscle cells at the postreceptor level. Am J Physiol Heart Circ Physiol 2006, 290:H538-546.

171. Bonnie J, Korach D, Korach KS: Estrogen receptors and human disease. $J$ Clin Invest 2006, 116:561-570.

172. Gaughwin PM, Caldwell MA, Anderson JM, Schwiening CJ, Fawcett JW, Compston DAS, Chandran S: Astrocytes promote neurogenesis from oligodendrocyte precursor cells. Eur J Neurosci 2006, 23:945-956.

173. Mori T, Buffo A, Gotz M: The novel roles of glial cells revisited: the contribution of radial glia and astrocytes to neurogenesis. Curr Top Dev Biol 2005, 69:67-99.

174. Zheng T, Marshal LL, Laywell ED, Steindler DA: Neurogenic astrocytes transplanted into the adult mouse lateral ventricle contribute to olfactory neurogenesis, and reveal a novel intrinsic subependymal neuron. J Neuroscience 2006, 142:175-185.

175. Kraev IV, Godukhin OV, Patrushev IV, Davies HA, Popov VI, Stewart MG: Partial kindling induces neurogenesis, activates astrocytes and alters synaptic morphology in the dentate gyrus of freely moving adult rats. J Neurosci 2009, 162:254-267.

176. Nakagawa T, Miyamoto O, Janjua NA, Auer RN, Nagao S, Itano T: Localization of nestin in amygdaloid kindled rat; an immunoelectron microscopic study. Can J Neurol Sci 2004, 31:514-519.

177. Williams S, Wagner PD: Transgenic animals in integrative biology: approaches and interpretations of outcome. J Appl Physiol 2000, 88:1119-1126.

178. Lindahl P, Karlsson L, Hellstrom M, Gebre-Medhin S, Willetts K, Health JK, Betsholtz C: Alveogenesis failure in PDGF-A-deficient mice is coupled to lack of distal spreading of alveolar smooth muscle cell progenitors during lung development. Development 1997, 124:3943-3953.

179. Soriano P: The PDGF alpha receptor is required for neural crest cell development and for normal patterning of the somites. Development 1997, 124:2691-2700.

180. Betsholtz C: Role of platelet-derived growth factors in mouse development. Int J Dev Biol 1995, 39:817-825.

doi:10.1186/2045-8118-8-8

Cite this article as: Bonkowski et al:: The CNS microvascular pericyte: pericyte-astrocyte crosstalk in the regulation of tissue survival. Fluids and Barriers of the CNS 2011 8:8.

\section{Submit your next manuscript to BioMed Central and take full advantage of:}

- Convenient online submission

- Thorough peer review

- No space constraints or color figure charges

- Immediate publication on acceptance

- Inclusion in PubMed, CAS, Scopus and Google Scholar

- Research which is freely available for redistribution

Submit your manuscript at www.biomedcentral.com/submit
C Biomed Central 